Barbosa, I.K.P.; Silva, M.C.B.C. Ecoturismo e etnoturismo na aldeia potiguara de Tramatáia, Área de Proteção Ambiental da Barra do Rio Mamanguape (PB). Anais do VIII Congresso Nacional de Ecoturismo e do IV Encontro Interdisciplinar de Ecoturismo em Unidades de Conservação. Revista Brasileira de Ecoturismo, São Paulo, v.4, n.4, 2011, p. 546.

\title{
ECOTURISMO E ETNOTURISMO NA ALDEIA POTIGUARA DE TRAMATÁIA, ÁREA DE PROTEÇÃO AMBIENTAL DA BARRA DO RIO MAMANGUAPE (PB)
}

\author{
Izolda Kelly Pereira Barbosa*, Maria Cristina Basílio Crispim da Silva* \\ *Universidade Federal da Paraíba \\ E-mails: izoldakelly.tour@gmail.com, ccrispim@hotmail.com
}

O turismo caracteriza-se como atividade econômica que se utiliza da comercialização de paisagens, muitas vezes reconhecidas como bens difusos, gerando assim certos impactos sociais, econômicos e ambientais, através da utilização dessas paisagens como um produto intangível, sejam elas naturais ou modificadas por ações antrópicas. Sua comercialização inclui também um conjunto de diversas outras atividades que servem para subsidiar seu desenvolvimento caracterizando sua interdisciplinaridade, sendo assim, cada tipo de paisagem acaba configurando um determinado tipo de turismo, que por sua vez se configura e se desdobra em vários outros segmentos. O ecoturismo e o etnoturismo são dois segmentos da atividade turística, que podem configurar-se em tipos de atividades econômicas sustentáveis quando bem planejadas. Dependendo da situação, esses dois segmentos do turismo podem apresentar aspectos negativos ou positivos em comunidades tradicionais e áreas naturais. Tendo em vista o incipiente, mas crescente desenvolvimento da atividade turística na área de estudo, discute-se nesse trabalho a possibilidade do desenvolvimento dessa atividade na aldeia Potiguara de Tramatáia. De acordo com a Empresa Brasileira de Pesquisa Agropecuária (EMBRAPA), a APA situa-se na mesorregião da zona da mata, litoral norte do estado da Paraíba, com uma distância de $70 \mathrm{~km}$ da cidade de João Pessoa, e limita-se ao norte com o município de Marcação onde se localiza a Aldeia, ao sul com o município de Lucena, a oeste com o município de Rio Tinto, e a leste com o Oceano Atlântico. Na APA situa-se o Projeto Peixe-Boi, um dos motivos pelo qual a localidade tem recebido turistas. Embora existam aspectos ambientais que propiciaram a criação da APA como a existência de um ecossistema estuarino e espécies endêmicas ameaçadas, nela os impactos ambientais decorrem de um processo histórico, advindos desde a época da colonização e que ainda hoje perduram através da cultura da cana-de-açúcar, da criação de viveiros de camarão, do desmatamento, entre outros que podem ser observados ao longo de quase todo o percurso de acesso à APA.Para tanto, objetivou-se fazer uma análise dos aspectos sociais, econômico e ambientais visando perceber possíveis impactos ou contribuições que o desenvolvimento desta atividade econômica possa gerar para a área em estudo levando-se em consideração o real significado do termo desenvolvimento. Através da pesquisa in locu, utilizandose da observação livre, da pesquisa qualitativa, de cunho fenomenológico, da análise de conteúdo, entrevista semi-estruturada, além de documentos técnicos, possibilitou-se ter uma visão ampliada do ambiente de estudo, sendo possível inferir que as pessoas da comunidade local que estão mais envolvidas com o desenvolvimento da atividade turística a considera relevante como uma atividade econômica complementar. A partir dessa perspectiva considera-se que o turismo pode ser utilizado como meio para valorizar os aspectos culturais que incluem o modo como a comunidade local se relaciona com o meio ambiente natural, através de das interpretações empíricas da própria comunidade, sendo ainda necessário uma maior preparação da comunidade local para o seu envolvimento no desenvolvimento turístico, que poderia ser possível através de políticas públicas direcionadas para esta temática.

Palavras-chave: Ecoturismo; Etnoturismo; Comunidade local. 